\title{
Fractionation of carbohydrates and protein and rumen degradation kinetic parameters of brachiaria grass silage enriched with rice bran
}

\author{
Fagton de Mattos Negrão ${ }^{1}$, Anderson de Moura Zanine ${ }^{2}$, Luciano da Silva Cabral ${ }^{3}$, Alexandre \\ Lima de Souza ${ }^{2}$, Guilherme Ribeiro Alves ${ }^{2}$, Daniele de Jesus Ferreira ${ }^{4}$, Carlos Clayton Oliveira \\ Dantas ${ }^{1}$, Aline Lehmkuhl ${ }^{5}$
}

\begin{abstract}
${ }_{1}^{1}$ Programa de Pós-graduação em Ciência Animal, Universidade Federal de Mato Grosso, Cuiabá, MT, Brasil.
2 Departamento de Zootecnia, Universidade Federal de Mato Grosso, Rondonópolis, MT, Brasil.

${ }^{3}$ Departamento de Zootecnia e Extensão Rural, Universidade Federal de Mato Grosso, Cuiabá, MT, Brasil.

${ }^{4}$ Programa de Pós-graduação em Zootecnia, Universidade Federal de Viçosa, Viçosa, MG, Brasil.

${ }^{5}$ Programa de Pós-graduação em Agricultura Tropical, Universidade Federal de Mato Grosso, Cuiabá, MT, Brasil.
\end{abstract}

\begin{abstract}
This experiment was conducted to evaluate the protein and carbohydrate fractions, and to estimate the in situ rumen degradation kinetic parameters of Brachiaria decumbens grass silage with inclusion of rice bran. Five rice bran inclusion levels were tested: $0,10,20,30$ and $40 \%$ of the natural matter, distributed into a completely randomized design with five replications. The brachiaria grass was obtained at 60 days of regrowth by cutting the forage at $10 \mathrm{~cm}$ from the soil and ensiling it in 10-L experimental silo bags, which were opened after 40 days. The degradability profiles for DM, CP, NDF and of the feeds for each animal utilized made it possible to obtain the estimates of the parameters analyzed. The contents of total carbohydrates $(\mathrm{TCH})$, fibrous carbohydrates and fraction $\mathrm{A}+\mathrm{B}_{1}$ of the TCH decreased linearly as the rice bran levels were elevated. Fraction A of the protein was increased linearly by $0.64 \%$ for every $1 \%$ of rice bran added to the silage. For nitrogenous fractions $\mathrm{B}_{3}$ and $\mathrm{C}$, there was a decrease of 0.11 and $0.40 \%$ for each $1 \%$ of rice bran added to the silage, respectively. For the rumen degradability parameters of the dry matter, fractions A and I had estimated increases of 0.54 and $0.04 \%$ for every $1 \%$ inclusion of rice bran. For the degradation rate of fraction B $(c)$, treatments had no effect. Fractions A and I of the crude protein degradability parameters increased by 0.22 and $0.72 \%$, respectively, with inclusion of $1 \%$ rice bran. Inclusion levels of rice bran had no effect on fraction $\mathrm{D}$, on the degradation rate of fraction $\mathrm{B}(c)$ or lag time (L) estimated for neutral detergent fiber. Inclusion of 10 and $20 \%$ rice bran in the brachiaria grass silage improves protein and carbohydrate fractions and rumen degradation kinetic parameters of dry matter, crude protein and neutral detergent fiber.
\end{abstract}

Key Words: by-products, forage conservation, nutritional value, roughage

\section{Introduction}

The Central-West Region of Brazil is characterized by presenting a strong climate seasonality, which determines the occurrence of well-defined seasons: one with elevated and another with reduced precipitation rates. Consequently, the forage grasses used for grazing cattle in Brazil produce less biomass at the times of water deficit. Under normal conditions, 10 to $30 \%$ of the production of tropical grasses utilized in the pasture areas occur in the period of water shortage (Macedo, 2005). Thus, to correct the nutritional requirements of herds in periods of low pasture productivity or even to meet the requirements of confinement, an alternative is conservation of forages in the form of silage.

Because of their high nutritional values and appropriate physicochemical properties, corn and sorghum are the preferred cultures for silage production. However, other forages such as grasses are alternatives for ensilage, because in addition to compensating the forage deficiency in the dry period, they present elevated potential for silage production because of their high forage potential and adequate nutritional value when harvested at the appropriate moment. However, the presence of high moisture at the ideal moment for harvesting and the low soluble-carbohydrate content are factors that limit the adequate fermentation process, resulting in silages of inferior quality, in addition to causing nutrient loss by the elevated amount of effluent produced (McDonald, 1981; Andrade and Lavezzo, 1998).

In an attempt to reduce the losses associated with the ensilage of grass, one of the main alternatives has been to increase the dry matter content by adding absorbent materials, which reduce losses, and improve the nutritional value of forage. Some additives can be employed in order to absorb the moisture of grass silages by controlling the production of effluent, such as coffee husks (Bernardino et al., 2005), 
wheat bran (Zanine et al., 2006ab), cassava chips (Zanine et al., 2010), rice bran, soybean hulls and corn meal (Monteiro et al., 2011), promoting increase in the nutritional value of the forage.

As a consequence of the possible alterations in the chemical composition of the grass silage that an additive may promote, determining the carbohydrate and protein fractions as well as the rumen degradation kinetic parameters of dry matter, crude protein and neutral detergent fiber of silages is of utmost importance to improve the silage nutritional value with inclusion of additives.

Furthermore, this information has been utilized in the most modern systems of diet adequacy for ruminants in order to enable the formulation of diets that optimize animal performance, associated with reduction in the emission of methane and nutrient loss via feces and urine (Tonani et al., 2001).

This research was conducted to evaluate the in situ rumen degradation of dry matter, crude protein and neutral detergent fiber and the fractionation of carbohydrates and proteins of brachiaria grass silages enriched with rice bran.

\section{Material and Methods}

The experiment was conducted at Universidade Federal do Mato Grosso, from November to March 2011. According to the Köppen classification, the climate is tropical, characterized by two well-defined seasons: dry (April to September) and rainy (October to March).

The forage species utilized was Brachiaria decumbens cv. Basilisk, from an already established pasture of approximately 0.5 ha. The experiment was set in a completely randomized design with five replications; treatments consisted of brachiaria grass and brachiaria grass with inclusion of $10,20,30$ or $40 \%$ rice bran, based on the natural matter of the grass (Table 1).

The grass was subjected to a standardization cut performed with a mower attached to a tractor at $5 \mathrm{~cm}$ above the soil. On the same day, the soil was fertilized with $60 \mathrm{~kg} \cdot \mathrm{ha}^{-1}$ nitrogen and potassium in the form of ammonium sulfate and potassium chloride, respectively. After 60 days of growth, the grass was cut mechanically at $10 \mathrm{~cm}$ above the soil, when it showed an average of $70 \mathrm{~cm}$ in height. At this stage, the grass has a high nutritional value. The grass was chopped into particles of approximately $3 \mathrm{~cm}$ in a stationary chopper (Nogueira EN-6500). After weighing, the rice bran was added to the forage mass and homogenized on a plastic canvas, according to the treatments, and then the material was manually compressed.
For the ensilage process, experimental silo bags with capacity of 10 liters and closed (sealed) with a Busen valve were used, remaining closed for 40 days. After this period, the silo bags were opened, and immediately after their removal, silage samples were pre-dried in a forcedventilation oven at $65^{\circ} \mathrm{C}$ for 48 hours, and then ground in a Wiley mill with a two-millimeter-screen sieve, according to recommendations of the AOAC (1990).

Samples were initially subjected to laboratory analysis for determination of dry matter, crude protein, ether extract and mineral matter contents. Total digestible nutrients (TDN) were determined according to Van Soest (1994) through the equation: $\operatorname{TDN}(\%)=\operatorname{Deg}+\left(1.25^{*} \mathrm{EE}\right)-\mathrm{MM}$. $(\mathrm{Deg}=$ degradability; 1.25 = correction factor; $\mathrm{EE}=$ ether extract; $\mathrm{MM}=$ mineral matter). The neutral detergent fiber content was determined according to Van Soest et al. (1991).

Afterwards, the fractions $\mathrm{A}+\mathrm{B}_{1}, \mathrm{~B}_{2}$ and $\mathrm{C}$ of carbohydrates were determined. They represent, respectively, the soluble sugars, starch and pectin; potentially digestible neutral detergent fiber; and the indigestible fraction of neutral detergent fiber. The percentage of total carbohydrates $(\mathrm{TCH})$ was obtained by the equation $\mathrm{TCH}=$ $100-(\% \mathrm{CP}+\% \mathrm{EE}+\%$ ash $)$; fibrous carbohydrates (FC), from the NDF corrected for its residual ash and protein contents (NDFap); non-fibrous carbohydrates (NFC), which correspond to fractions $\mathrm{A}+\mathrm{B}_{1}$, by the difference between total carbohydrates; and NDFap (Hall, 2003) was determined according to methodologies described by Sniffen et al. (1992). Fraction C corresponds to the indigestible NDF after 144 hours of in situ incubation (Cabral et al., 2004). Fraction $B_{2}$, which corresponds to the available fraction of the fiber, was obtained by the difference between NDFap and fraction $C$.

Protein fractions $\left(\mathrm{A}, \mathrm{B}_{1}+\mathrm{B}_{2}, \mathrm{~B}_{3}\right.$ and $\left.\mathrm{C}\right)$ were determined, in which fraction $\mathrm{A}$ corresponds to non-protein nitrogen (NPN), which has a high hydrolysis rate in the rumen;

Table 1 - Mean values of nutritional composition and hemicellulose of brachiaria grass silages according to the levels of rice bran, and rice bran values

\begin{tabular}{lcccccc}
\hline \multirow{2}{*}{ Variable } & \multirow{5}{c}{ Rice bran } & \multicolumn{5}{c}{ Rice bran levels (\%) } \\
\cline { 2 - 7 } & & 0 & 10 & 20 & 30 & 40 \\
\hline Dry matter $^{1}$ & 90.01 & 22.21 & 28.50 & 33.63 & 36.07 & 40.11 \\
Crude protein $^{2}$ & 16.06 & 5.78 & 7.62 & 9.47 & 11.32 & 13.16 \\
Ether extract $^{2}$ & 16.14 & 2.08 & 5.36 & 9.15 & 11.71 & 14.33 \\
NDF $^{2}$ & 26.89 & 30.42 & 26.10 & 21.77 & 17.45 & 13.13 \\
ADF $^{2}$ & 13.76 & 26.87 & 24.17 & 21.17 & 18.89 & 16.25 \\
TDN $^{2}$ & 83.64 & 38.05 & 46.32 & 54.83 & 61.22 & 65.90 \\
Hemicellulose $^{2}$ & 11.34 & 57.24 & 50.27 & 43.31 & 36.35 & 29.38 \\
\hline
\end{tabular}

NDF - neutral detergent fiber; ADF - acid detergent fiber; TDN - total digestible nutrients.

${ }^{1}$ Percentage.

${ }^{2}$ Percentage in dry matter. 
fraction B represents the true protein which is subdivided into three sub-fractions, based on the ruminal degradation speed: $\mathrm{B}_{1}$ is rapidly degraded in the rumen ( $>50 \%$ /hour), represented by albumin and globulin; $\mathrm{B}_{2}$, with intermediate degradation rate $(5-15 \%$ /hour), is mostly represented by albumins and glutelins. Fractions $\mathrm{B}_{1}+\mathrm{B}_{2}$ were obtained by the difference between fraction $\mathrm{A}$ and the neutral detergent insoluble nitrogen (NDIN) content, as reported by Licitra et al. (1996). Fraction $\mathrm{B}_{3}$, the protein associated with the cell wall, of slow degradation (0.01-1.5\%/hour), is represented by prolamins, extensins and denatured proteins, obtained by the difference between the NDIN and ADIN contents. Lastly, fraction $\mathrm{C}$ corresponds to the acid detergent insoluble nitrogen (ADIN). Neutral detergent insoluble nitrogen and ADIN were obtained by treating the sample with neutral and acid detergent solutions for 1 hour at $100{ }^{\circ} \mathrm{C}$, respectively, and subsequently, the content of nitrogenous compounds in each residue was determined (Sniffen et al., 1992).

The non-protein nitrogen content (fraction A) was calculated as the difference between the percentage of total nitrogen in the sample and the protein nitrogen contained in the residue after treating the sample with a $10 \%$ trichloroacetic acid solution for thirty minutes. After, the nitrogen content in the residue was estimated by the Macro Kjedal method according to Cappelle et al. (2001).

For the in situ assay, four non-lactating, non-pregnant, rumen-fistulated crossbred cows of $400 \mathrm{~kg}$ average body weight were maintained on brachiaria grass pastures and received supply of mineral supplement ad libitum at the trough. Feedstuffs ground to $2 \mathrm{~mm}$ were weighed and placed in non-woven textile (TNT) bags, to provide 10 to 20 milligrams of sample $\mathrm{cm}^{-2}$ of useful area of the bags, according to the methodology of Nocek (1988), using 9 bags for each feedstuff, in which each animal represented one replication. Bags were heat-sealed and conditioned in a shade-tissue bag with $100 \mathrm{~g}$ of lead (to prevent bags from remaining only at the dorsal part of the rumen), tied with a nylon wire and inserted in the rumen at 0, 2, 4, 8, 16, 24, 48, 72, 96 and 144 hours and removed at the same time. For all incubation times, nine bags were weighed per time, per feedstuff. Bags corresponding to time zero hour were only incubated in the rumen for washing. The shade-tissue bag was attached to the cap of the cannula with a $50 \mathrm{~cm}$ long nylon wire for the material to lodge in the ventral sac of the rumen.

After incubation, bags were removed from the rumen at the same time and washed in running water for approximately 30 minutes to remove the excess rumen content. Subsequently, the bags were exhaustively washed in running water until it was clear, then sent to the Laboratory of Animal Nutrition, where they were then predried in a forced-ventilation oven at $65^{\circ} \mathrm{C}$ for 48 hours, according to the AOAC (1990). After removed from the oven and in equilibrium with room temperature, the bags were weighed. The dry matter was determined in an oven at $65^{\circ} \mathrm{C}$ for 48 hours and the residue obtained after this step was utilized for analysis.

The in situ rumen degradation data of DM, CP, NDF and iNDF were calculated as the difference found for each component between the weights before and after rumen incubation, expressed as percentage of the original material in the bags, so it was possible to build rumen degradation profiles. To estimate the rumen degradation kinetic parameters of DM and $\mathrm{CP}$, the first-order asymptotic exponential model was used, according to Orskov and Mcdonald (1979), and for the neutral detergent fiber (NDF) degradation profile, the model of Mertens (1987) was employed.

By these models, for the dry matter and crude protein contents, the following components were estimated: fraction A, corresponding to the water-soluble fraction of DM which disappears from bags at time zero; fraction B, corresponding to the water-insoluble fraction potentially degradable in the rumen as a function of time; $c$ is the rumen degradation rate of fraction $\mathrm{B}$, expressed in $\mathrm{h}^{-1}$; and fraction $\mathrm{I}$, which corresponds to the rumen-indigestible fraction of $\mathrm{DM}$ or CP, i.e., the residue of the feed that remained in bags after 144 hours of incubation. For the neutral detergent fiber, however, the following were estimated: fraction D, which corresponds to the rumen-potentially degradable part of the NDF; $c$ is the rumen-degradation rate of fraction D, expressed as percentage per hour; and $L$, which corresponds to the rumen-indigestible fraction of the neutral detergent fiber, i.e., the residue of the feed remaining in the bags after 144 hours of rumen incubation, according to Orskov and McDonald (1979).

The degradability profiles for DM, CP, NDF and of the feeds for the each animal utilized, which were subjected to adjustment by the respective models, utilizing procedure "Regressão de Marquardt" of software SAEG (Sistema para Análises Estatísticas e Genéticas, version 8.1), made it possible to obtain the estimates of the parameters analyzed. The data obtained were analyzed statistically by variance analysis ( $t$ test) and in the case of significance $(\mathrm{P}<0.05)$, regression analysis was performed, testing the polynomial models of first and second degrees, utilizing software SAEG (Sistema para Análises Estatísticas e Genéticas, version 8.1). 


\section{Results and Discussion}

The total carbohydrates $(\mathrm{TCH})$ in the brachiaria grass silage showed linear reduction $(\mathrm{P}<0.05$; Table 2$)$, with an estimated decrease of $0.16 \%$ for each $1 \%$ of rice bran added to the grass silage. This reduction can be related to the higher protein content and ether extract of the rice bran (Table 1). Carvalho et al. (2007) found a reduction of $0.22 \%$ for each $1 \%$ addition of cocoa meal to elephant grass silage. Contrary results to the present study were reported by Andrade et al. (2010), in which the cocoa meal levels caused a linear increase in the TCH content, estimated at $0.28 \%$ for each $1 \%$ additive, possibly caused by the lower $\mathrm{CP}$ and $\mathrm{EE}$ contents of the cocoa meal compared with the rice bran, used in the present study.

Linear reduction $(\mathrm{P}<0.05)$ was observed for the fibrous carbohydrates (FC) of the brachiaria grass silages, in which every $1 \%$ addition of rice bran promoted a decrease of $1.15 \%$ in the FC content (Table 2). They correspond to the available and unavailable fiber, which are represented by hemicellulose and cellulose, along with the lignin being partially available in the rumen, thus with greater efficiency at making energy available for ruminants (Mertens, 1987). Conflicting results were recorded by Andrade et al. (2010), who evaluated the effect of $0,10,20$ and $30 \%$ coffee husks in elephant grass silage and observed linear increase in FC. The authors reported that the additive elevated $1.01 \%$ of this fraction with the inclusion of $1 \%$ coffee husks in the elephant grass forage at the moment of ensilage, probably due to the higher NDF content of the coffee husks as compared with the rice brain utilized herein.

Non-fibrous carbohydrates were affected linearly $(\mathrm{P}<0.05)$ by the inclusion of rice bran levels in the silage (Table 2), with an estimated $1.0 \%$ for every $1 \%$ addition of rice bran to the ensilage of brachiaria grass. Fractions $\mathrm{A}+\mathrm{B}_{1}$ of the silages correspond to the soluble carbohydrates completely available in the gastrointestinal tract of ruminants. Andrade et al. (2010) evaluated the addition of cassava meal and cocoa meal to the silage of elephant grass and observed linear increase $(\mathrm{P}<0.05)$ in the $\mathrm{A}+\mathrm{B}_{1}$ fraction of carbohydrates, promoting an increase of 1.5 and $0.8 \%$ for every $1 \%$ addition of the respective additives.

Feeds with an elevated $A+B_{1}$ fraction are considered good energy sources to stimulate growth of rumen microorganism (Carvalho et al., 2007) and the synchronism between the protein and carbohydrate digestion rates, having an important effect on the end products of fermentation and on animal production (Nocek, 1988). In this context, the starch present in rice bran contributed to increase in the $\mathrm{A}+\mathrm{B}_{1}$ fraction of silages. The highest NFC content, represented by fractions $\mathrm{A}+\mathrm{B}_{1}$, would theoretically increase the TDN content, since these carbohydrates present almost complete digestion for ruminants (Mertens, 1993; Cabral et al., 2003).

There was quadratic behavior $(\mathrm{P}<0.05)$ for fraction $\mathrm{B}_{2}$ of the $\mathrm{TCH}$, which correspond to the cell wall components, with an estimated minimum value $36.66 \%$ for the level of $19.25 \%$ of the additive (Table 2). Similar behavior was reported by Dantas (2012), who observed quadratic behavior in the potentially degradable fraction $\left(\mathrm{B}_{2}\right)$ of the brachiaria grass silage containing inclusion of $0,20,30$ and $40 \%$ ground soybean hulls, observing a minimum of $6.6 \%$ inclusion of the by-product in brachiaria grass at the moment of ensilage.

Fraction $\mathrm{B}_{2}$, for presenting a slow degradation rate, along with fraction $\mathrm{C}$ (indigestible), usually affects animal intake by the rumen fill, which can reduce animal performance (Mertens, 1987). Malafaia et al. (1998) point out that the fraction $\mathrm{B}_{2}$ value of the feeds is related to the NDF content, because in studies conducted with several feeds, it was demonstrated that grasses were the roughages with the highest fraction $\mathrm{B}_{2}$ values, due to the greater NDF contents, which explains the higher values of this fraction in control silage.

For every $1 \%$ of inclusion of rice bran in the brachiaria grass silage, there was a reduction of $0.98 \%$ in fraction $\mathrm{C}$

Table 2 - Mean values of total carbohydrates, fibrous carbohydrates and fractions $\mathrm{A}+\mathrm{B}_{1}, \mathrm{~B}_{2}$ and $\mathrm{C}$ of brachiaria grass silages containing increasing levels of rice bran

\begin{tabular}{|c|c|c|c|c|c|c|c|c|}
\hline \multirow{2}{*}{ Variable } & \multicolumn{5}{|c|}{ Rice bran levels (\%) } & \multirow{2}{*}{ Regression equation $^{1}$} & \multirow{2}{*}{$\mathrm{CV} \%$} & \multirow{2}{*}{$\mathrm{R}^{2}$} \\
\hline & 0 & 10 & 20 & 30 & 40 & & & \\
\hline Total carbohydrates ${ }^{2}$ & 81.99 & 79.04 & 77.35 & 76.38 & 74.83 & $Y=81.318-0.169 X$ & 1.91 & 95.88 \\
\hline Fibrous carbohydrates $^{2}$ & 66.58 & 46.77 & 32.31 & 26.91 & 17.97 & $Y=63.898-1.153 X$ & 2.29 & 94.52 \\
\hline Fraction $^{3} \mathrm{~A}+\mathrm{B}_{1}$ & 15.41 & 32.26 & 45.03 & 49.46 & 56.85 & $\mathrm{Y}=19.791+1.000 \mathrm{X}$ & 3.92 & 94.22 \\
\hline Fraction $^{3} \mathrm{~B}_{2}$ & 39.00 & 40.48 & 41.33 & 40.24 & 38.39 & $\mathrm{Y}=38.952+0.231-0.006 \mathrm{X}^{2}$ & 1.71 & 98.41 \\
\hline Fraction $^{3} \mathrm{C}^{2}$ & 45.59 & 27.26 & 13.64 & 10.30 & 4.76 & $\mathrm{Y}=40.029-0.986 \mathrm{X}$ & 5.71 & 90.58 \\
\hline
\end{tabular}

$\mathrm{CV}$ - coefficient of variation.

${ }^{1}$ Significant at $5 \%$ probability by the t test.

${ }^{2}$ Percentage in dry matter

${ }^{3}$ Percentage in total carbohydrates. 
(\% TCH) (Table 2). Similar behavior was observed by Andrade et al. (2010), who evaluated the inclusion of cassava meal in elephant grass silage and recorded a linear reduction in the fraction $\mathrm{C}$ of the silage, whose estimated decrease was of $0.45 \%$ for every $1 \%$ additive. It is worth mentioning that such behavior can favor voluntary intake by animals, which is a determinant factor in animal husbandry. Contrasting results were observed by Carvalho et al. (2007), who recorded an increase of $0.2 \%$ for every unit of cocoa meal added to the elephant grass at the moment of ensilage, probably due to the higher NDF content of the cocoa meal in relation to the rice bran, used in the present study.

Determining the characteristics of the protein fractions of feeds allows us to estimate their respective contents as well as the greater or lower escape of rumen nitrogen. With this information it is possible to develop nutritional strategies to improve the use of nitrogen by both rumen microorganisms and the animal. As a consequence, the level of utilization of the nitrogenous fraction is important at the evaluation of feeds and at the specification of nutritional requirements of ruminants (Cabral et al., 2000).

Fraction A, which represents the percentage of nonprotein nitrogen $(\mathrm{NPN})$, increased linearly $(\mathrm{P}<0.05)$, with an estimated increase of $0.64 \%$ for every $1 \%$ of rice bran included (Table 3 ). This result can be explained by the high $\mathrm{CP}$ of rice bran (16.06\%), and this protein was possibly converted into non-protein nitrogen for being highly susceptible to proteolysis (Van Soest, 1994).

Contrary results were reported by Carvalho et al. (2008), who observed that the NPN content decreased linearly as the cocoa meal levels increased, with an estimated reduction of $0.68 \%$ for every $1 \%$ of the additive included in the elephant grass silage, probably because of the lower CP content in the cocoa meal in relation to the ensiled grass. Santos et al. (2012) reported that the different components of mesquite (meal, pods and starch) utilized in the ensilage of elephant grass contributed to the increase of fraction $\mathrm{A}$ in the rumen degradability of DM and $\mathrm{CP}$ of silages.

Fractions $\mathrm{B}_{1}$ and $\mathrm{B}_{2}$ in this study, considered a single fraction $\left(\mathrm{B}_{1}+\mathrm{B}_{2}\right)$, referring to the true soluble and insoluble proteins, behaved quadratically $(\mathrm{P}<0.05)$, with maximum estimated value of $15.5 \%$ for the level of $28.75 \%$ additive (Table 3). According to Sniffen et al. (1992), because it presents rapid rumen degradation rate in relation to fraction $\mathrm{B}_{3}$, fraction $\mathrm{B}_{1}+\mathrm{B}_{2}$ tends to be extensively degraded in the rumen, contributing to meet the nitrogen requirements of rumen microorganisms; however, the rapid proteolysis of these fractions in the rumen can lead to accumulation of peptides and enable their escape into the intestines, given that the use of peptides is considered limiting to the degradation of proteins. Andrade et al. (2010) observed maximum decrease of $0.452 \%$ in the $\mathrm{B}_{1}+\mathrm{B}_{2}$ content of the elephant grass containing cassava meal as additive.

Decreasing linear effect $(\mathrm{P}<0.05)$ was verified for the protein contents associated with the cell wall and of slow rumen degradation, represented by fraction $\mathrm{B}_{3}$, as a percentage of total nitrogen, with an estimated reduction of $0.11 \%$ for every $1 \%$ rice bran added to the grass at the moment of ensilage. Andrade et al. (2010), studying the inclusion of agricultural by-products in elephant grass silages, concluded that the increase in the cassava meal levels had linear effect $(\mathrm{P}<0.05)$ on the contents of this fraction, promoting an increase of $0.34 \%$ for every $1 \%$ cassava meal added to the elephant grass at ensilage. In spite of being digestible, this protein fraction $\left(\mathrm{B}_{3}\right)$ has a rumen degradation rate of 0.02 to $1.0 \% \mathrm{~h}^{-1}$ (Sniffen et al., 1992). In addition, fraction $B_{3}$ is represented by the protein fraction of slow degradation bound to the cell wall (Cabral et al., 2004; Carvalho et al., 2008).

The fraction considered indigestible $(\mathrm{C}, \% \mathrm{TCH})$, however, measured by the quantification of the acid detergent insoluble nitrogen (ADIN) content in the silages, presented decreasing linear effect, with an estimated reduction of $0.40 \%$ for every $1 \%$ rice bran. These results agree with Andrade et al. (2010), who observed linear decreasing effect of the inclusion of cassava meal in the elephant grass silage, which presented an estimated decrease of $0.13 \%$ for every $1 \%$ cassava meal added.

According to Van Soest (1994), the increase in the fraction $\mathrm{C}$ of silages can occur due to the formation of

Table 3 - Mean values of the nitrogenous fractions (Fractions $A, B_{1}+B_{2}, B_{3}$ and $C$ ) of brachiaria grass silages containing rice bran levels

\begin{tabular}{|c|c|c|c|c|c|c|c|c|}
\hline \multirow{2}{*}{ Variable } & \multicolumn{5}{|c|}{ Rice bran levels (\%) } & \multirow{2}{*}{ Regression equation $^{1}$} & \multirow{2}{*}{$\mathrm{CV} \%$} & \multirow{2}{*}{$\mathrm{R}^{2}$} \\
\hline & 0 & 10 & 20 & 30 & 40 & & & \\
\hline Fraction $\mathrm{A}^{2}$ & 27.78 & 36.35 & 44.64 & 50.12 & 53.12 & $Y=29.512+0.644 X$ & 1.22 & 96.63 \\
\hline Fraction ${ }^{2} \mathrm{~B}_{1}+\mathrm{B}_{2}$ & 21.94 & 18.67 & 16.70 & 15.28 & 17.73 & $Y=22.140-0.460 X+0.008 X^{2}$ & 5.90 & 96.40 \\
\hline Fraction ${ }^{2} \mathrm{~B}_{3}$ & 15.56 & 14.75 & 13.40 & 12.25 & 10.95 & $Y=15.730-0.117 X$ & 7.47 & 99.43 \\
\hline Fraction $^{2} \mathrm{C}^{3}$ & 34.72 & 30.23 & 25.26 & 22.35 & 18.20 & $Y=34.326-0.409 X$ & 3.64 & 99.35 \\
\hline
\end{tabular}

$\mathrm{CV}$ - coefficient of variation.

${ }^{1}$ Significant at $5 \%$ probability by the t test.

${ }^{2}$ Percentage in total nitrogen. 
products of the Maillard reaction, given the increase in temperature in silages with elevated moisture content. It is possible that the increase in the fraction $\mathrm{C}$ of silages with rice bran is associated with the process of buffing the rice kernels in the cereal industry. It is believed that the Maillard reaction might have occurred in this phase, given the low ADIN values in this co-product in relation to brachiaria grass, thus resulting in decrease in the fraction $\mathrm{C}$ of those silages containing rice bran.

Because the proportion of these protein fractions is responsible for the greater or lower escape of ruminal nitrogen and for meeting the nitrogen requirements of rumen microorganisms, it is implicit that feeds with similar $\mathrm{CP}$ contents but with differences in these fractions will result in incorrect predictions of animal performance if one does not consider the dynamics of such fractions in the rumen and in the intestines during the formulation of diets (Malafaia, 1998).

The fraction $\mathrm{A}$ of the degradability parameters of DM increased linearly $(\mathrm{P}<0.05)$ by $0.54 \%$ for every $1 \%$ of inclusion of rice bran in the silage. Rêgo et al. (2009) observed linear increase with the inclusion of dried cashew apple in the ensilage of elephant grass, estimating that for every $1 \%$ of the additive there was an increase of $0.64 \%$ in this fraction. This result was similar to those observed by Rêgo et al. (2010), who studied elephant grass silages with inclusion of $0,4,8,12$ and $16 \%$ of annatto seeds. The authors reported that the values of the soluble fraction (A) of DM increased with the inclusion of the annatto seeds, varying from 19.50 to $26.25 \%$.

The insoluble and potentially degradable fraction of the DM, fraction $\mathrm{B}$, reduced linearly $(\mathrm{P}<0.05$; Table 4$)$ by $0.59 \%$ for every $1 \%$ addition of rice bran to the silage. The potentially degradable fraction (B) of DM stayed between 64.79 and $40.86 \%$ with inclusion of 0 and $40 \%$ rice bran, respectively. These are values close to those observed by Pereira et al. (2000), who worked with elephant grass with addition of waste from the processing of corn and soy, obtaining potentially degradable fractions between 43.43 and $53.20 \%$, respectively.
Concerning the ruminal degradation rate of fraction $\mathrm{B}$ (c), no significant difference $(\mathrm{P}>0.05)$ was observed for the inclusion levels of rice bran, showing mean value of $0.016 \mathrm{~h}^{-1}$ (Table 4). For all inclusion levels of rice bran, the degradation rate of DM remained within the range of 2 to $6 \%$ per hour, which is a characteristic of good-quality feeds (Sampaio, 1988).

The inclusion of rice bran in brachiaria grass silages affected the concentration of the indigestible fraction (I) of DM. Increasing linear effect $(\mathrm{P}<0.05)$ was observed, with an estimation of increase of $0.04 \%$ for every $1 \%$ rice bran (Table 4). Similarly, Monteiro et al. (2011) verified increase in the fiber contents of the elephant grass silages with addition of $20 \%$ soybean hulls. The authors verified that this fact can be associated with the elevated structural components (cellulose and hemicellulose) present in the cell wall of the co-product.

Increasing linear behavior $(\mathrm{P}<0.05)$ was observed for the degradability rate of the highly water-soluble part of the $\mathrm{CP}$, represented by fraction $\mathrm{A}$, with an estimated increase of $0.22 \%$ for each $1 \%$ rice bran. Similar results were found by Rêgo et al. (2010), who observed increasing linear behavior in the elephant grass silage containing $0,4,8,12$ and $16 \%$ of the co-product of annatto seeds. A lower fraction A value than those observed in this study was recorded by Chizzotti et al. (2005), who evaluated the ruminal degradability of the elephant grass silage and verified $29.3 \%$ for fraction A. Part of the soluble fraction of CP is available in the form of NPN, as suggested by Sniffen et al. (1992) and Cabral et al. (2002) and proven by Cabral et al. (2004), who found $56.9 \% \mathrm{NPN}$ when fractionating the nitrogenous compounds of elephant grass silage.

Fraction B, represented by the water-insoluble part potentially degradable over time, behaved in a decreasing linear manner $(\mathrm{P}<0.05)$ as the rice bran levels were added. A decrease of $0.29 \%$ was estimated for every $1 \%$ additive in the ensilage of brachiaria grass (Table 5). Considering the values estimated by the fraction B degradability equation, the inclusion levels of $0,10,20,30$ and $40 \%$ rice bran led to a reduction of 50.45, 47.52, 44.59 and $38.73 \%$, respectively.

Table 4 - Mean values of the degradability parameters of fractions A and B and degradation rate of fractions B (c) and I of dry matter (DM) of brachiaria grass silages containing rice bran levels

\begin{tabular}{|c|c|c|c|c|c|c|c|c|}
\hline \multirow{2}{*}{ Variable } & \multicolumn{5}{|c|}{ Rice bran levels (\%) } & \multirow{2}{*}{ Regression equation $^{1}$} & \multirow{2}{*}{$\mathrm{CV} \%$} & \multirow{2}{*}{$\mathrm{R}^{2}$} \\
\hline & 0 & 10 & 20 & 30 & 40 & & & \\
\hline Fraction A & 24.01 & 29.95 & 37.49 & 40.91 & 45.99 & $Y=24.690+0.549 X$ & 2.99 & 98.59 \\
\hline Fraction $\mathrm{B}$ & 64.79 & 58.44 & 50.79 & 46.57 & 40.86 & $Y=64.243-0.597 X$ & 1.79 & 99.19 \\
\hline$c\left(h^{-1}\right)$ & 0.015 & 0.015 & 0.016 & 0.016 & 0.016 & $Y=0.016$ & 11.56 & - \\
\hline Fraction I & 11.18 & 11.59 & 11.70 & 12.50 & 13.13 & $Y=11.066+0.048 X$ & 6.44 & 94.17 \\
\hline
\end{tabular}

$\mathrm{CV}$ - coefficient of variation; A - water-soluble fraction (of DM) that disappears from bags at time zero; B - water-insoluble fraction potentially degradable over time; $\mathrm{c}$ - ruminal degradation rate of fraction B, expressed in \%/hour; I - rumen-indigestible fraction of dry matter, i.e., the residue of the remaining feed in the bags after 144 hours of incubation. ${ }^{1}$ Significant at $5 \%$ probability by the $\mathrm{t}$ test. 
These results were contrary to those found by Dantas (2012), who recorded fraction B degradability values at a linear increase of $28.48,32.78,37.09$ and $45.71 \%$ in the brachiaria grass silage with the inclusion levels of $0,20,30$ and $40 \%$ ground soybean hulls, respectively.

The degradation rate of fraction B $(c)\left(\mathrm{h}^{-1}\right)$, which represents the passage rate of the feed through the digestive system of the animal, grew linearly $(\mathrm{P}<0.05)$, with an estimated increase of $0.0005 \%$ for every $1 \%$ rice bran (Table 5). Rêgo et al. (2009) reported that the degradation rate of fraction $\mathrm{B}(c)$ of $\mathrm{CP}$ showed highest value with the inclusion of $4 \%$ dried cashew apple, reducing according to the inclusion levels of the additive.

Fraction I, represented by the undegradable part, behaved linearly $(\mathrm{P}<0.05)$, with an estimated increase of $0.72 \%$ for every $1 \%$ rice bran. Rodrigues (2007) suggests that the elevated proportion of carbohydrates of the cell wall and the lignin content of the forage are the main causes of the lower degradability. Thus, the lower degradability values of this fraction observed in the silage with $100 \%$ brachiaria grass can be attributed to the greater proportion of these components.

There was no significant difference $(\mathrm{P}>0.05)$ for the potentially degradable fraction of NDF, represented by fraction D (Table 6), according to the inclusion levels of rice bran at the moment of ensilage of the brachiaria grass, showing mean value of $50.94 \%$. According to Cabral (2002), the knowledge of the fractions that make up the NDF (D and I) is of paramount importance, because we can assume that the non-degradable fraction (I) has a significant effect on the indigestibility of feeds.

The degradation rate of fraction $\mathrm{D}(c)$, which represents the time of permanence of the potentially soluble fraction in the digestive tract of animals, did not suffer any influence $(\mathrm{P}>0.05)$ from inclusion of rice bran, averaging $0.051 \%$ (Table 6). According to Chizzotti et al. (2005), the variation in the degradation rate of fraction $\mathrm{D}(\mathrm{c})$ is due to the preference of rumen bacteria for different types of plant tissues. This observation is consistent with the fact that greater levels of additive may or may not favor the microbial population in the rumen, responsible for the degradation of non-structural carbohydrates prevailing in the silages. Neutral detergent fiber degradation rates between 2 and $6 \%$ per hour are considered good for roughage feeds of quality (Mertens, 1993).

No significant effect $(\mathrm{P}>0.05)$ of the inclusion of the co-product could be observed in relation to lag time (L), which is the time during which the component (NDF) is not digested (average 6.87 hours) (Table 6). Such behavior was similar to the observed by Dantas (2012), who evaluated levels from 0 to $40 \%$ ground soybean hulls in the ensilage of brachiaria grass and verified mean values of 5.62 hours for this fraction, corresponding to the initial events of action of the rumen microbiota, such as adherence to the substrate and synthesis of enzymes.

Linear behavior $(\mathrm{P}<0.05)$ was observed for the indigestible fraction (I) of the NDF of brachiaria grass silages according to the inclusion levels of rice bran

Table 5 - Mean values of the degradability parameters of fractions A and B and degradation rate of fractions B (c) and I of the crude protein (CP) of brachiaria grass silages enriched with rice bran levels

\begin{tabular}{|c|c|c|c|c|c|c|c|c|}
\hline \multirow{2}{*}{ Variable } & \multicolumn{5}{|c|}{ Rice bran levels (\%) } & \multirow{2}{*}{ Regression equation $^{1}$} & \multirow{2}{*}{$\mathrm{CV} \%$} & \multirow{2}{*}{$\mathrm{R}^{2}$} \\
\hline & 0 & 10 & 20 & 30 & 40 & & & \\
\hline Fraction A & 36.50 & 39.33 & 40.67 & 42.67 & 45.89 & $\mathrm{Y}=36.592+0.221 \mathrm{X}$ & 3.26 & 98.15 \\
\hline Fraction B & 50.97 & 46.81 & 44.35 & 42.16 & 38.60 & $Y=50.456-0.293 X$ & 2.58 & 98.74 \\
\hline$c\left(\% h^{-1}\right)$ & 0.039 & 0.042 & 0.057 & 0.058 & 0.060 & $\mathrm{Y}=0.039+0.0005 \mathrm{X}$ & 7.15 & 87.02 \\
\hline Fraction I & 12.50 & 13.82 & 14.93 & 15.12 & 15.47 & $\mathrm{Y}=12.952+0.724 \mathrm{X}$ & 7.40 & 88.77 \\
\hline
\end{tabular}

$\mathrm{CV}$ - coefficient of variation; A - water-soluble fraction of the crude protein that disappears from bags at time zero; B - water-insoluble fraction potentially degradable over time; $\mathrm{c}$ - ruminal degradation rate of fraction B, expressed in \%/hour; I - rumen-indigestible fraction of dry matter, i.e., the residue of the remaining feed in the bags after 144 hours of incubation.

${ }^{1}$ Significant at $5 \%$ probability by the $t$ test.

Table 6 - Mean values of the degradability parameters of fractions D, degradation rate of fraction B (c), L and I of the neutral detergent fiber (NDF) of brachiaria grass silages enriched with rice bran levels

\begin{tabular}{|c|c|c|c|c|c|c|c|c|}
\hline \multirow{2}{*}{ Variable } & \multicolumn{5}{|c|}{ Rice bran levels (\%) } & \multirow{2}{*}{ Regression equation $^{1}$} & \multirow{2}{*}{$\mathrm{CV} \%$} & \multirow{2}{*}{$\mathrm{R}^{2}$} \\
\hline & 0 & 10 & 20 & 30 & 40 & & & \\
\hline Fraction D & 48.75 & 50.65 & 51.29 & 51.94 & 52.09 & $Y=50.94$ & 2.35 & - \\
\hline$c\left(\% h^{-1}\right)$ & 0.026 & 0.048 & 0.056 & 0.062 & 0.065 & $\mathrm{Y}=0.051$ & 44.22 & - \\
\hline Lag time (hours) & 6.80 & 6.83 & 6.87 & 6.91 & 6.95 & $Y=6.87$ & 10.12 & - \\
\hline Fraction I & 44.42 & 42.47 & 41.78 & 41.08 & 40.89 & $\mathrm{Y}=43.809-0.084 \mathrm{X}$ & 2.35 & 81.44 \\
\hline
\end{tabular}

CV - coefficient of variation; D - rumen-potentially degradable fraction of the NDF; c - degradation rate of fraction D, expressed in \%/hour; L - lag time (hours); I - rumenindigestible fraction of neutral detergent fiber, i.e., the residue of the remaining feed in the bags after 144 hours of incubation.

${ }^{1}$ Significant at $5 \%$ probability by the $t$ test. 
(Table 6), with an estimated reduction of $0.84 \%$ for each $1 \%$ inclusion of the additive. The lower NDF content of rice bran compared with ensiled brachiaria grass was possibly the reason for the reduction of this fraction. Cabral et al. (2002) explains that the reduction of this fraction can be considered beneficial, since it implies increase in energy for the animal organism.

\section{Conclusions}

Inclusion of 10 to $20 \%$ rice bran in the silage of brachiaria grass improves the protein and carbohydrate proportions as well as the rumen degradation kinetic parameters of dry matter, crude protein and neutral detergent fiber.

\section{References}

Andrade, J. B. and Lavezzo, W. 1998. Aditivos na ensilagem de capimelefante. Composição bromatológica das forragens e das respectivas silagens. Pesquisa Agropecuária Brasileira 33:1859-1872.

Andrade, I. V. O.; Pires, A. J. V.; Carvalho, G. G. P.; Veloso, C. M. and Bonomo, P. 2010. Perdas, características fermentativas e valor nutritivo da silagem de capim-elefante contendo subprodutos agrícolas. Revista Brasileira de Zootecnia 39:2578-2588.

AOAC - Association of Official Analitical Chemists. 1990. Official methods of analysis. 15th ed. v.1. Arlington, VA.

Bernardino, F. S.; Garcia, R.; Rocha, F. C.; Souza, A. L. and Pereira, O. G. 2005. Produção e características do efluente e composição bromatológica da silagem de capim-elefante contendo diferentes níveis de casca de café. Revista Brasileira de Zootecnia 34:2185-2191.

Cabral, L. S.; Valadares Filho, S. C.; Malafaia, P. A. M.; Lana, R. P.; Silva, J. F. C.; Vieira, R. A. M. and Pereira, E. S. 2000. Frações protéicas de alimentos tropicais e suas taxas de digestão estimadas pela incubação com proteases ruminais. Revista Brasileira de Zootecnia 29:2316-2324.

Cabral, L. S.; Valadares Filho, S. C.; Detmann, E.; Zervoudakis, J. T.; Pereira, O. G.; Veloso, R. G. and Pereira, E. S. 2002. Cinética ruminal das frações de carboidratos, produção de gás, digestibilidade in vitro da matéria seca e NDT estimado da silagem de milho com diferentes proporções de grãos. Revista Brasileira de Zootecnia 31:2332-2339.

Cabral, L. S.; Valadares Filho, S. C.; Detmann, E.; Zervoudakis, J. T.; Pereira, O. G.; Nunes, P. M. M.; Veloso, R. G. and Pereira, E. S. 2003. Composição químico-bromatológica, produção de gás, digestibilidade in vitro da matéria seca e NDT estimado da silagem de sorgo com diferentes proporções de panículas. Revista Brasileira de Zootecnia 32:1250-1258

Cabral, L. S.; Valadares Filho, S. C.; Detmann, E.; Zervoudakis, J. T.; Veloso, R. G. and Nunes, P. M. M. 2004. Taxas de digestão das frações protéicas e de carboidratos para as silagens de milho e de capim-elefante, o feno de capim-tifton- 85 e o farelo de soja. Revista Brasileira de Zootecnia 33:1573-1580.

Cappelle, E. R.; Valadares Filho, S. C.; Silva, J. F. C. and Cecon, P. R. 2001. Estimativas do valor energético a partir de características químicas e bromatológicas dos alimentos. Revista Brasileira de Zootecnia 30:1837-1856.

Carvalho, G. G. P.; Garcia, R.; Pires, A. J. V.; Pereira, O. G.; Fernandes, F. E. P.; Obeid, J. A. and Carvalho, B. M. A. 2007. Fracionamento de carboidratos de silagem de capim-elefante emurchecido ou com farelo de cacau. Revista Brasileira de Zootecnia 36:1000-1005.

Carvalho, G. G. P.; Garcia, R.; Pires, A. J. V.; Detmann, E.; Pereira, O. G. and Fernandes, F. E. P. 2008. Degradação ruminal de silagem de capim-elefante emurchecido ou com diferentes níveis de farelo de cacau. Revista Brasileira de Zootecnia 37:1347-1354.

Chizzotti, M. L.; Valadares Filho, S. C.; Leão, M. I.; Valadares, R. F. D.; Chizzotti, F. H. M.; Magalhães, K. A. and Marcondes, M. I. 2005. Casca de algodão em substituição parcial a silagem de capimelefante para novilhos. Consumo, degradabilidade e digestibilidade total e parcial. Revista Brasileira de Zootecnia 34:2093-2102.

Dantas, C. C. O. 2012. Perdas e valor nutritivo de silagens de Brachiaria aditivadas com casca de soja. Dissertação (M.Sc.). Universidade Federal de Mato Grosso, Cuiabá.

Hall, M. B. 2003. Challenges with nonfiber carbohydrate methods. Journal of Animal Science 81:3226-3232.

Licitra, G.; Hernandes, T. M. and Van Soest, P. J. 1996. Standardization of procedures for nitrogen fractionational of ruminant feeds. Animal Feed Science and Technology 57:347-358.

Macedo, M. C. M. 2005. Pastagens no ecossistema cerrados: evolução das pesquisas para o desenvolvimento sustentável. p.56-84. In: Anais da 42를 Reunião Anual da Sociedade Brasileira de Zootecnia. UFG; SBZ, Goiânia.

Malafaia, P. A. M.; Valadares Filho, S. C.; Vieira, R. A. M. et al. 1998. Determinação das frações que constituem os carboidratos totais e da cinética ruminal da fibra em detergente neutro de alguns alimentos para ruminantes. Revista Brasileira de Zootecnia 27:790-796.

McDonald, P. 1981. The biochemistry of silage. John Wiley e Sons, Chichester.

Mertens, D. R. 1987. Predicting intake and digestibility using mathematical models of ruminal function. Journal Animal Science 64:1548-1558

Mertens, D. R. 1993. Rate and extent of digestion. p.13-51. In: Quantitative aspects of ruminant digestion and metabolism. Forbes, J. M. and France, J., eds. CAB International, Wallingford.

Monteiro, I. J. G.; Abreu, J. G.; Cabral, L. S.; Ribeiro, M. D. and Reis, R. H. P. 2011. Silagem de capim-elefante aditivada com produtos alternativos. Acta Scientiarum 33:347-352.

Nocek, J. E. 1988. In situ and others methods to estimate ruminal protein and energy digestibility. Journal Dairy Science 71:2051-2069.

Orskov, E. R and McDonald, I. 1979. The estimation of protein degrability in the rumem from incubation measurements weighted acoording to rate of passage. Journal of Agricultural Science 92:499-503.

Pereira, E. S.; Paiva, P. C. A.; Tiesenhausen, I. M. E. V.; Pozza, P. C. and Arruda, A. M. V. 2000. Degradação da matéria seca, proteína bruta e fibra em detergente neutro de silagens de capim-elefante adicionadas de resíduos do beneficiamento do milho e da soja. Revista Brasileira de Zootecnia 29:2354-2358

Rêgo, A. C.; Teles, M. M.; Neiva, J. N. M.; Candido, M. J. D.; Feitosa, J. V. and Gomes, F. H. T. 2009. Degradação da matéria seca, proteína bruta e fibra em detergente neutro de silagens de capimelefante contendo pedúnculo de caju desidratado. Ciência Animal Brasileira 10:735-744.

Rêgo, A. C.; Cândido, M. J. D.; Pereira, E. S.; Feitosa, J. M. and Rêgo, M. M. T. 2010. Degradação de silagens de capim-elefante contendo subproduto do urucum. Revista Ciência Agronômica 41:482-489.

Rodrigues, R. 2007. Uso de diferentes aditivos em silagem de capimelefante. Revista Brasileira de Saúde e Produção Animal 8:66-79.

Sampaio, I. B. M. 1988. Experimental designs and modeling techniques in the study of roughage degradation in rumen and growth of ruminants. Tese (D.Sc.). University of Reading, Reading. 
Santos, S.; Santos-Cruz, C. L.; Rocha, J. B.; Pires, A. J. V.; Santos, Í. P. A.; Lima, T. R. and Junqueira, R. S. 2012. Degradação ruminal da silagem de capim-elefante com diferentes componentes da algaroba. Revista Brasileira de Saúde e Produção Animal 13:123-136.

Sniffen, C. J.; O’Connor, J. D.; Van Soest, P. J.; Fox, D. G. and Russel, J. B. 1992. A net carbohydrate and protein system for evaluation cattle diets. II. Carbohydrate and protein availability. Journal Animal Science 70:3562-3577.

Tonani, F. L.; Ruggieri, A. C.; Queiroz, A. C. and Andrade, P. 2001. Degradabilidade ruminal in situ da matéria seca e da fibra em detergente neutro em silagens de híbridos de sorgo colhidos em diferentes épocas. Arquivo Brasileiro de Medicina Veterinária e Zootecnia 23:100-104.

Van Soest, P. J.; Robertson, J. B. and Lewis, B. A. 1991. Methods for dietary fiber, neutral detergent fiber, and nonstarch polyssacarides in relation to animal nutrition. Journal of Dairy Science 74:3583-3597.

Van Soest, P. J. 1994. Nutritional ecology of the ruminant. Cornell University, Ithaca.

Zanine, A. M.; Santos, E. M.; Ferreira, D. J.; Pereira, O. G. and Almeida, J. C. C. 2006a. Efeito do farelo de trigo sobre as perdas, recuperação da matéria seca e composição bromatológica de silagem de capim-mombaça. Brazilian Journal of Veterinary Research and Animal Science 43:803-809.

Zanine, A. M.; Santos, E. M.; Ferreira, D. J.; Oliveira, J. S.; Almeida, J. C. C. and Pereira, O. G. 2006b. Avaliação da silagem de capimelefante com adição de farelo de trigo. Arquivos de Zootecnia 55:75-84.

Zanine, A. M.; Santos, E. M.; Dorea, J. R. R.; Dantas, P. A. S.; Silva, T. C. and Pereira, O. G. 2010. Evolution of elephant-grass silage with the addition of cassava scrapings. Revista Brasileira de Zootecnia 12:2611-2616. 